\title{
Papers
}

\section{Role of multivitamins and mineral supplements in preventing infections in elderly people: systematic review and meta-analysis of randomised controlled trials}

\author{
Alia El-Kadiki, Alexander J Sutton
}

\begin{abstract}
Objective To evaluate the effectiveness of multivitamins and mineral supplements in reducing infections in an elderly population.

Design Systematic review and meta-analysis of randomised controlled trials.

Data sources Medline and other databases. Reference lists of identified articles were inspected for further relevant articles. Selection of studies Trials were included if they evaluated the effect of multivitamins and mineral supplements on infections in an elderly population.

Review methods Studies were assessed for the methodological quality by using the Jadad instrument. If the data required for the analyses were not available from the published articles we requested them from the original study authors. Meta-analysis was undertaken on three outcomes: the mean difference in number of days spent with infection, the odds ratio of at least one infection in the study period, and the incidence rate ratio for the difference in infection rates. Data on adverse events were also extracted.

Results Eight trials met our inclusion criteria. Owing to inconsistency in the outcomes reported, only a proportion of the trials could be included in each meta-analysis. Multivitamins and mineral supplements were found to reduce the mean annual number of days spent with infection (three studies) by 17.5 (95\% confidence interval 11 to $24, \mathrm{P}<0.001)$. The odds ratio for at least one infection in the study period (three studies) was $1.10(0.81$ to $1.50, \mathrm{P}=0.53)$. The infection rate ratio (four studies) was 0.89 ( 0.78 to $1.03, \mathrm{P}=0.11)$. Reporting of adverse events was poor.

Conclusion The evidence for routine use of multivitamin and mineral supplements to reduce infections in elderly people is weak and conflicting. Study results are heterogeneous, and this is partially confounded by outcome measure.
\end{abstract}

\section{Introduction}

Elderly people constitute the fastest growing population segment of societies in the developed world. ${ }^{1}$ In the United Kingdom the number of people older than 85 will continue to double every 30 years (1961: 300 000; 1991: 800 000; 2021: $1500000)^{2}$ Ageing is associated with physiological and economical changes that compromise nutritional status. ${ }^{3}$ In addition, ageing has long been associated with an increased susceptibility to infections, which are very common in older people.
Moreover, elderly people are two to 10 times more likely to die of a variety of infections than are young adults. ${ }^{4}$

Public interest in vitamin supplements is enormous: $20-30 \%$ of the population in developed countries currently use such supplements. ${ }^{5}$ Millions of people worldwide take multivitamin and mineral supplements, hoping to promote health, but few studies have documented their benefits, which has raised concern in the literature recently. ${ }^{56}$ It has been shown that in elderly people, supplementation with different nutrients improves immune status. Most of these studies looked at the effect of micronutrients on vaccine responses and other surrogate markers of immune response. $^{7-16}$ The clinical importance of these findings is still a subject of debate; some believe that the micronutrients have a major role ${ }^{17}$ and others believe that they have only a minor role ${ }^{18}$ in reducing the frequency of infections in elderly people.

We undertook a systematic review and meta-analysis of randomised controlled trials evaluating the use of multivitamin and mineral supplements to prevent infections in an elderly population. We focus on studies that evaluate multivitamin and mineral supplements and exclude those that investigate single vitamins or minerals since multivitamin supplements are more widely used.

\section{Methods}

We searched computerised publication databases to identify relevant randomised controlled trials (AMED, Biological Abstracts, British Nursing Index, CINAHL, Citation Indexes (Science and Social Sciences), Cochrane Database of Systematic Reviews (CDSR), Database of Abstracts of Reviews of Effects (DARE), EBM Reviews, Embase, International Bibliographic Information on Dietary Supplements (IBIDS), Medline, NHS Centre for Reviews and Dissemination databases, and PreMedline). The searches covered the period from 1966 to the first week of January 2004. We supplemented this search by examining published reviews, guidelines, Health Evidence Bulletin Wales, and conference abstracts (for details of the specific search strategies used, see appendix 1 on bmj.com). We scrutinised the reference lists of identified relevant articles to identify any further studies missed by the previous searches.

\section{Selection}

In order to be included in the review, a study had to be a randomised placebo controlled trial, evaluating a combination of

Search strategies are on bmj.com 
multivitamins and mineral supplements in an elderly population. Studies also had to report an infection related outcome.

\section{Data extraction and quality assessment}

After an initial scoping exercise on the included trial reports, we decided to focus our attention on the three most widely used and reported outcomes: the mean difference in number of days spent with infection, the odds ratio of at least one infection in the study period, and the incidence rate ratio for the difference in infection rates. Additionally, we extracted any data on adverse events. The authors extracted all outcome data relating to infections and where disagreements existed they reached consensus through discussion. If data required for the planned analyses were not available from the published reports, we wrote to the corresponding authors of the primary studies and requested the necessary information. We used the Jadad scoring system to assess the methodological quality of the individual randomised controlled trials. $^{19}$

\section{Quantative data synthesis}

We used random effects models to perform meta-analyses if the heterogeneity between studies was estimated to be greater than zero; otherwise we used the model reduced to a fixed effect model. We used weighted Poisson regression to combine the continuous outcome (the mean difference in number of days of infection over 12 months) on the mean difference scale, the binary outcome (one or more infections during the study period) on the $(\log )$ odds ratio scale, and the incidence rate (the rate of infections during the study period).

Although we intended to use funnel plots to assess the possibility of publication bias, the relatively small number of studies reporting each outcome precluded such an assessment. Similarly, we had planned to use meta-regression to assess heterogeneity between studies, but this was not possible because of the limited data available. We undertook this review and reported it in accordance with the guidelines set out in the QUOROM statement. ${ }^{20}$ We used Stata, version 8.2 (StataCorp, College Station, TX: StataCorp LP, 2003) for all statistical analyses.

\section{Results}

Figure 1 outlines the results of the trial selection process. We screened a total of 1490 abstracts from the combined searches. This identified 36 potentially relevant studies, but on obtaining and reading the articles, only eight met the inclusion criteria. ${ }^{21-28}$ All eight trials were placebo controlled. Table 1 provides details on design characteristics and quality assessment scores for the included studies. Variability between studies is considerable with respect to duration of follow-up, infections assessed, and number of subjects. Jadad scores were reasonable for all studies except one ${ }^{27}$ but this probably, at least in part, reflects the brevity of the study report. Table 1 also notes that three of the trials ${ }^{28} 2522$ used a $2 \times 2$ factorial trial, and only the two most relevant arms are included in this meta-analysis. Table 2 gives the exact formulation of the multivitamin and mineral interventions given in each trial and indicates where differences between trials exist (these differences are considered further in the discussion).

As indicated in the methods, the outcome measures reported across the trials were not standardised. Table 3 provides a matrix indicating which trials reported which outcomes and could therefore be included in each meta-analysis.

\section{Meta-analysis of first outcome}

Three trials ${ }^{23}{ }^{26}{ }_{27}$ reported mean difference of number of days spent with infections on multivitamins and minerals compared

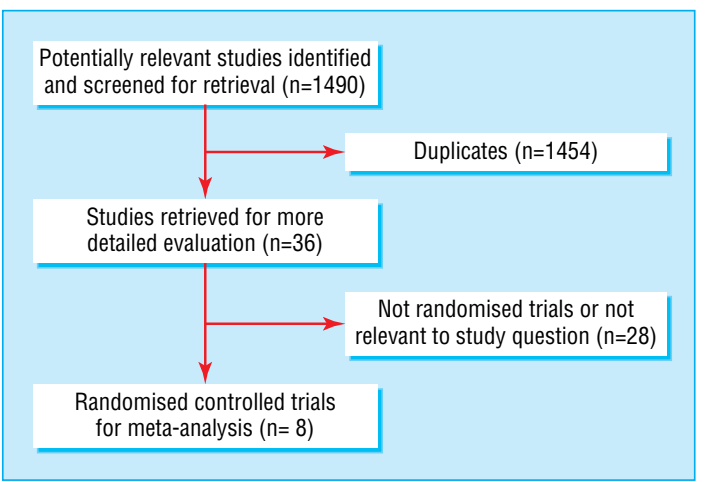

Fig 1 Results of literature search and selection of randomised controlled trials for the meta-analyses. Values are numbers of trials (QUOROM statement flow diagram)

with placebo over 12 months. Data are provided in figure 2, indicating that all three trials individually show a (significant) reduction in days of infection for the multivitamin and mineral group and the pooled estimate of a benefit of approximately 17.5 days $(95 \%$ confidence interval 11 to 24$)$ is highly significant $(\mathrm{P}<0.001)$. Although the direction of results is consistent, studies are heterogeneous (the $I^{2}$ statistic, which indicates the proportion of variability in the weighted mean differences attributable to heterogeneity, is estimated to be $97.3 \%$, which is considered (very) large)..$^{29}$ We had a concern that the reported standard deviations for this outcome seemed to be very small and may in fact be standard errors. Hence we performed an extreme sensitivity analysis in which we re-analysed the data under the assumption that this error had been made (by inflating the reported values by multiplying them by the number of subjects minus 1) in all three trials; the pooled estimate remained similar and still significant (14 day benefit, 10 to $18, \mathrm{P}<0.001$ ).

\section{Meta-analysis of second outcome}

Three trials ${ }^{22} 24{ }^{25}$ reported at least one infection during the study period for vitamins and minerals compared with placebo. As figure 3 indicates, the odds ratios for two of the three studies included are greater than one, and the pooled odds ratio is 1.10 (0.81 to 1.50 ) (this is a fixed effect analysis as the between study heterogeneity was estimated as zero). Hence this meta-analysis provides little support for the benefit of multivitamin and minerals; however, the wide confidence interval makes the findings inconclusive $(\mathrm{P}=0.53)$.

\section{Meta-analysis of third outcome}

Four trials ${ }^{2125} 2728$ reported the incidence rate ratio of infection for vitamins and minerals compared with placebo. The pooled incident risk ratio for the fixed effect model is 0.89 (0.78 to 1.03; fig 4). Hence there is an indication that multivitamins and minerals may reduce the number of infections, but this does not reach conventional significance levels $(\mathrm{P}=0.11)$.

\section{Reporting of adverse events}

Reporting of adverse event outcomes for the trials was so incomplete that meta-analysis was not possible. We summarise the data that could be extracted. One trial reported some dropouts (four in the treatment group and one in the placebo group) because of nausea, which in our interpretation could be attributable to the intervention. ${ }^{24}$ Two further trials indirectly implied that no adverse events causing dropout occurred (by citing the presence of adverse events in other studies using higher doses). ${ }^{22}{ }^{28}$ Two more trials stated clearly that there were no drop- 


\begin{tabular}{|c|c|c|c|c|c|c|c|}
\hline Study (location) & $\begin{array}{l}\text { Age of trial } \\
\text { participants in } \\
\text { years }\end{array}$ & $\begin{array}{l}\text { Duration of } \\
\text { follow-up }\end{array}$ & Infections assessed & $\begin{array}{c}\text { No of subjects in placebo } \\
\text { group }\end{array}$ & $\begin{array}{l}\text { No of subjects in } \\
\text { treatment group }\end{array}$ & $\begin{array}{l}\text { Jadad } \\
\text { score }\end{array}$ & Comments \\
\hline $\begin{array}{l}\text { Chavance et al } \\
1993 \text { (France) }^{21}\end{array}$ & $60+$ & 4 months & $\begin{array}{l}\text { Respiratory, nose, throat, } \\
\text { ear, skin, mouth, urinary, } \\
\text { and gynaecological } \\
\text { infections }\end{array}$ & $\begin{array}{l}108 \text { (of which } 7 \text { were lost to } \\
\text { follow-up, leaving an } \\
\text { effective sample size of 101) }\end{array}$ & $\begin{array}{c}110 \text { (of which } 7 \text { were lost } \\
\text { to follow-up, leaving an } \\
\text { effective sample size of } \\
103 \text { ) }\end{array}$ & 3 & Double blind \\
\hline $\begin{array}{l}\text { Girodon et al } 1999 \\
{\text { (France })^{22}}^{22}\end{array}$ & $65+$ & $\begin{array}{c}2 \text { years } \\
\text { (maximum) }\end{array}$ & $\begin{array}{l}\text { Respiratory and } \\
\text { symptomatic urogenital } \\
\text { infections }\end{array}$ & $\begin{array}{l}182 \text { (of which } 4 \text { withdrew } \\
\text { and } 51 \text { died during the } \\
\text { study, but all were included } \\
\text { in analysis) }\end{array}$ & $\begin{array}{l}181 \text { (of which } 3 \text { withdrew } \\
\text { and } 55 \text { died during the } \\
\text { study, but all were } \\
\text { included in analysis) }\end{array}$ & 4 & $\begin{array}{l}\text { A double blind, } 2 \times 2 \text { factorial } \\
\text { trial (arms multivitamin only } \\
\text { and minerals only excluded } \\
\text { from meta-analyses) } \\
\text { Population was from nursing } \\
\text { homes }\end{array}$ \\
\hline $\begin{array}{l}\text { Chandra } 1992 \\
\quad(\text { United States })^{23}\end{array}$ & $65+$ & 12 months & $\begin{array}{l}\text { Any infection (diagnosis } \\
\text { was based on clinical } \\
\text { features and laboratory } \\
\text { tests included blood } \\
\text { count, radiography of the } \\
\text { chest and sinuses, } \\
\text { bacterial and fungal } \\
\text { cultures of sputum, urine } \\
\text { and blood, C reactive } \\
\text { protein, and erythrocyte } \\
\text { sedimentation rate) }\end{array}$ & 48 & 48 & 4 & Double blind \\
\hline $\begin{array}{l}\text { Barringer et al } \\
2003 \text { (United } \\
\text { States) } \text { ) }^{24}\end{array}$ & $65+$ & 12 months & $\begin{array}{l}\text { Upper respiratory tract } \\
\text { infection, lower } \\
\text { respiratory tract infection, } \\
\text { influenza-like syndrome, } \\
\text { gastrointestinal infection, } \\
\text { and urinary tract infection }\end{array}$ & 17 & $\begin{array}{c}1865 \text { (2 dropped out } \\
\text { and were lost to } \\
\text { follow-up leaving an } \\
\text { effective sample size of } \\
16 \text { ) }\end{array}$ & 4 & $\begin{array}{l}\text { People aged }<65 \text { years were } \\
\text { excluded from the analysis. A } \\
\text { large proportion of subjects } \\
\text { had diabetes. Double blind }\end{array}$ \\
\hline $\begin{array}{l}\text { Graat et al 2002, } \\
\text { (Netherlands) }^{25}\end{array}$ & $60+$ & $\begin{array}{l}15 \text { months } \\
\text { (maximum) }\end{array}$ & $\begin{array}{l}\text { Acute respiratory tract } \\
\text { infections }\end{array}$ & 230 & 240 & 3 & $\begin{array}{l}\text { A double blind, } 2 \times 2 \text { factorial } \\
\text { trial. Arms of vitamin } E \text { only } \\
\text { and multivitamin+mineral }+ \\
\text { vitamin } E \text { have been excluded } \\
\text { from meta-analyses }\end{array}$ \\
\hline $\begin{array}{l}\text { Chandra } 2002 \\
\text { (location not }^{2} \\
\text { specified) })^{26}\end{array}$ & $50-65$ & 12 months & $\begin{array}{l}\text { Common adult infection } \\
\text { illnesses diagnosed by } \\
\text { fever, cough, elevated } \\
\text { erythrocyte sedimentation } \\
\text { rate and C reactive } \\
\text { protein, } x \text { ray of the } \\
\text { sinuses and chest, blood } \\
\text { culture, sputum culture, } \\
\text { and urine culture }\end{array}$ & $\begin{array}{l}22 \text { (three lost to follow-up, } \\
\text { leaving an effective sample } \\
\text { size of 19) }\end{array}$ & 22 & 4 & Double blind \\
\hline Jain 2002 (India) $^{27}$ & $51-78$ & 12 months & Respiratory infections & 18 & 18 & 2 & Blinding unclear \\
\hline $\begin{array}{l}\text { Girodon et al } 1997 \\
{\text { (France })^{28}}\end{array}$ & $65+$ & 2 years & $\begin{array}{l}\text { Respiratory and } \\
\text { symptomatic urogenital } \\
\text { infections }\end{array}$ & $\begin{array}{l}20 \text { (of which } 7 \text { dropped out } \\
\text { before end but were } \\
\text { included in analysis) }\end{array}$ & $\begin{array}{l}21 \text { (of which } 7 \text { dropped } \\
\text { out before end but were } \\
\text { included in analysis) }\end{array}$ & 4 & $\begin{array}{l}\text { A double blind, } 2 \times 2 \text { factorial } \\
\text { trial (arms multivitamin only } \\
\text { and minerals only excluded } \\
\text { from meta-analysis) } \\
\text { Population was from nursing } \\
\text { homes }\end{array}$ \\
\hline
\end{tabular}

outs owing to the effects of the intervention. ${ }^{25}{ }^{26}$ No mention of adverse events was given in the remaining three trials. ${ }^{21} 2327$

\section{Discussion}

The evidence for the effectiveness of the routine use of multivitamins in an elderly population to reduce infections is of poor to moderate quality, heterogeneous, and conflicting. We found little evidence of adverse events due to the intervention, but this may be due to poor reporting. It is worth noting that other studies using excessive micronutrient supplements (in larger doses than implemented in any of the trials reviewed here) have been shown to have toxic effects and may impair cellular function. ${ }^{30}$

The potential underlying mechanism by which multivitamins and minerals generally and specifically prevent infections is still uncertain; we do not know whether is it related to improvement in immunity, improvement of the underlying deficiency, or other reasons.

Although formal meta-regression to explore potential reasons for the observed heterogeneity was not possible because of the small numbers of studies reporting each outcome, we qualitatively consider potential factors that may influence outcome below. Table 2 gives details of the exact composition of multivitamin and mineral supplements, and these differences in composition may in part be responsible. Two studies used dosages of nutrients that were close to recommended dietary allowances in France and the United States. ${ }^{22}{ }^{28}$ Three studies used nutrient dosages similar to the recommended dietary allowance in the United States, with the exception of vitamin $\mathrm{E}$ and $\beta$ carotene. ${ }^{23}{ }^{26}{ }^{27}$ Two studies used a daily oral tablet that contained amounts of vitamins and minerals similar to those found in most commercial multivitamin and mineral supplements, ${ }^{21}$ and one study used dosages at the level of recommended dietary allowances for vitamins and 25-50\% of recommended dietary allowances for minerals. ${ }^{25}$ Table 2 shows a comparison with recommended daily allowances in the United Kingdom.

A further potential explanation for heterogeneous results is variability in the baseline nutritional status of study participants. Differences were certainly considerable in the baseline rates of infection in the control groups of the four trials reporting infection rates (fig 4). Further, two trials ${ }^{24}$ even had marked imbalances in nutrient deficiencies at baseline. The subject populations recruited differed between studies (table 1, final col- 
Table 2 Details of composition of multivitamin and mineral supplements given in each trial

\begin{tabular}{|c|c|}
\hline Details & Daily intake of supplements \\
\hline \multicolumn{2}{|l|}{ Study (Iocation) } \\
\hline Chavance et al 1993 (France) $)^{21}$ & $\begin{array}{l}\text { Vitamins A (retinol } 5000 \mathrm{IU} \text { ), B1 (thiamine) } 2.25 \mathrm{mg} \text {, } \\
\text { B2 (riboflavin) } 2.6 \mathrm{mg}, \text { B6 (pyridoxine) } 3 \mathrm{mg}, \mathrm{B} 12 \\
\text { (cyanocobalamin) } 9 \mu \mathrm{g} \text {, C } 90 \mathrm{mg} \text {, D2 } 400 \mathrm{IU}, \mathrm{E} 30 \\
\mathrm{IU} \text {, nicotinamid } 20 \mathrm{mg} \text {, biotin } 45 \mu \mathrm{g} \text {, pantothenic acid } \\
10 \mathrm{mg} \\
\text { Calcium } 162 \mathrm{mg} \text {, iron } 27 \mathrm{mg} \text {, zinc } 22.5 \mathrm{mg} \text {, folic acid } \\
0.4 \mathrm{mg} \text {, phosphorus } 125 \mathrm{mg} \text {, iodine } 150 \mu \mathrm{g} \text {, } \\
\text { magnesium } 100 \mathrm{mg} \text {, copper } 3 \mathrm{mg} \text {, manganese } 7.5 \\
\mathrm{mg} \text {, potassium } 7.5 \mathrm{mg}\end{array}$ \\
\hline Girodon et al 1999 (France) ${ }^{22}$ & $\begin{array}{l}\text { Vitamins A ( } \beta \text { carotene } 6 \mathrm{mg} \text { ), C } 120 \mathrm{mg}, \mathrm{E} 15 \mathrm{mg} \\
\text { Zinc } 20 \mathrm{mg} \text {, selenium } 100 \mu \mathrm{g}\end{array}$ \\
\hline Chandra 1992 (United States) ) $^{23}$ & $\begin{array}{l}\text { Vitamins A (retinol } 400 \mu \mathrm{g} \text { ), B1 (thiamine) } 2.2 \mathrm{mg} \text {, } \\
\text { B2 (riboflavin) } 1.5 \mathrm{mg}, \text { niacin } 16 \mathrm{mg}, \mathrm{B} 6 \text { (pyridoxine) } \\
3.0 \mathrm{mg}, \mathrm{B} 124.0 \mu \mathrm{g}, \text { C } 80 \mathrm{mg}, \mathrm{D} 4 \mu \mathrm{g}, \mathrm{E} 44 \mathrm{mg} \text {, } \\
\text { Calcium } 200 \mathrm{mg} \text {, iron } 16 \mathrm{mg} \text {, zinc } 14 \mathrm{mg} \text {, folate } 400 \\
\mu \mathrm{g} \text {, copper } 1.4 \mathrm{mg} \text {, selenium } 20 \mu \mathrm{g} \text {, iodine } 0.2 \mathrm{mg} \text {, } \\
\text { magnesium } 100 \mathrm{mg} \text {. }\end{array}$ \\
\hline Barringer et al 2003 (United States) ${ }^{24}$ & $\begin{array}{l}\text { Vitamin A } 4000 \mathrm{IU} \text { ( } \beta \text { carotene } 1000 \mathrm{IU} \text { ), B1 } \\
\text { (thiamine) } 4.5 \mathrm{mg}, \mathrm{B} 2 \text { (riboflavin) } 3.4 \mathrm{mg} \text {, niacin } 20 \\
\mathrm{mg}, \mathrm{B} 6 \text { (pyridoxine) } 6 \mathrm{mg}, \mathrm{B} 12 \text { (cyanocobalamin) } 30 \\
\mu \mathrm{g}, \mathrm{C} \text { (ascorbic acid) } 120 \mathrm{mg}, \mathrm{D} 400 \mathrm{IU}, \mathrm{E} 60 \mathrm{IU}, \mathrm{K} \\
20 \mu \mathrm{g} \text {, biotin } 0.03 \mathrm{mg} \text {, pantothenic acid } 15 \mathrm{mg} \\
\text { Calcium } 120 \mathrm{mg} \text {, iron } 16 \mathrm{mg} \text {, folic acid } 400 \mu \mathrm{g} \text {, zinc } \\
22.5 \mathrm{mg}, \text { selenium } 105 \mu \mathrm{g} \text {, magnesium } 100 \mathrm{mg} \text {, } \\
\text { copper } 2 \mathrm{mg} \text {, iodine } 150 \mu \mathrm{g} \text {, manganese } 4 \mathrm{mg} \text {, } \\
\text { chromium } 180 \mu \mathrm{g}\end{array}$ \\
\hline Graat et al 2002, (Netherlands) ${ }^{25}$ & $\begin{array}{l}\text { A capsule contained: } \\
\text { Vitamins A (retinol } 600 \mu \mathrm{g}, \beta \text { carotene } 1.2 \mathrm{mg} \text { ), B1 } \\
\text { (thiamine) } 1.4 \mathrm{mg}, \mathrm{B} 2 \text { (riboflavin) } 1.6 \mathrm{mg} \text {, niacin } 18 \\
\mathrm{mg}, \mathrm{B} 6 \text { (pyridoxine) } 2.0 \mathrm{mg}, \mathrm{B} 12 \text { (cyanocobalamin) } 1 \\
\mu \mathrm{g}, \text { biotin } 150 \mu \mathrm{g}, \mathrm{C} 60 \mathrm{mg}, \mathrm{E} 10 \mathrm{mg}, \mathrm{D} \\
\text { (cholecalciferol) } 5 \mu \mathrm{g}, \mathrm{K} 30 \mu \mathrm{g} \text {, pantothenic acid } 6 \\
\mathrm{mg} \\
\text { Calcium } 74 \mathrm{mg} \text {, iron } 4.0 \mathrm{mg} \text {, folic acid } 200 \mu \mathrm{g} \text {, zinc } \\
10 \mathrm{mg} \text {, selenium } 25 \mu \mathrm{g} \text {, magnesium } 30 \mathrm{mg} \text {, copper } \\
1.0 \mathrm{mg} \text {, iodine } 100 \mu \mathrm{g} \text {, phosphorus } 49 \mathrm{mg} \text {, } \\
\text { manganese } 1.0 \mathrm{mg} \text {, chromium } 25 \mu \mathrm{g} \text {, molybdenum } \\
25 \mu \mathrm{g} \text {, silicium } 2 \mu \mathrm{g} \\
\text { Each participant received } 2 \text { capsules per day }\end{array}$ \\
\hline $\begin{array}{l}\text { Chandra } 2002 \text { (location not } \\
\text { specified) }^{26}\end{array}$ & $\begin{array}{l}\text { Vitamins A (retinol } 400 \mu \mathrm{g} \text { ), B1 (thiamine) } 2.2 \mathrm{mg} \text {, } \\
\text { B2 (riboflavin) } 1.5 \mathrm{mg}, \text { niacin } 16 \mathrm{mg}, \mathrm{B} 6 \text { (pyridoxine) } \\
3.0 \mathrm{mg}, \mathrm{B} 124.0 \mu \mathrm{g}, \mathrm{C} 80 \mathrm{mg}, \mathrm{D} 4.0 \mu \mathrm{g}, \mathrm{E} 44 \mathrm{mg} \\
\text { Calcium } 200 \mathrm{mg} \text {, iron } 16 \mathrm{mg} \text {, zinc } 14 \mathrm{mg} \text {, copper } 1.4 \\
\mathrm{mg} \text {, selenium } 20 \mu \mathrm{g} \text {, iodine } 200 \mu \mathrm{g} \text {, magnesium } 100 \\
\mathrm{mg} \text {, folate } 400 \mu \mathrm{g}\end{array}$ \\
\hline Jain 2002 (India) $^{27}$ & $\begin{array}{l}\text { Vitamins A (retinol } 400 \mu \mathrm{g} \text { ), B1 (thiamine) } 2.2 \mathrm{mg} \text {, } \\
\text { B2 (riboflavin) } 1.5 \mathrm{mg} \text {, niacin } 16 \mathrm{mg}, \mathrm{B} 6 \text { (pyridoxine) } \\
3.0 \mathrm{mg}, \mathrm{B} 124.0 \mu \mathrm{g}, \mathrm{E} 44 \mathrm{mg} \\
\text { Calcium } 200 \mathrm{mg} \text {, iron } 16 \mathrm{mg} \text {, zinc } 14 \mathrm{mg} \text {, copper } 1.4 \\
\mathrm{mg} \text {, selenium } 20 \mu \mathrm{g} \text {, iodine } 200 \mu \mathrm{g} \text {, magnesium } 100 \\
\mathrm{mg} \text {, folate } 400 \mu \mathrm{g}\end{array}$ \\
\hline Girodon et al 1997 (France) ${ }^{28}$ & $\begin{array}{l}\text { Vitamins A ( } \beta \text { carotene } 6 \mathrm{mg} \text { ), C } 120 \mathrm{mg} \text {, E } 15 \mathrm{mg} \\
\text { Zinc } 20 \mathrm{mg} \text {, selenium } 100 \mu \mathrm{g}\end{array}$ \\
\hline \multicolumn{2}{|c|}{ Recommended daily allowances in the United Kingdom } \\
\hline Men $\geq 50^{3132}$ & $\begin{array}{l}\text { Vitamins A } 700 \mu \mathrm{g}, \mathrm{B} 1 \text { (thiamine) } 0.9 \mathrm{mg}, \mathrm{B} 2 \\
\text { (riboflavin) } 1.3 \mathrm{mg} \text {, niacin } 16 \mathrm{mg}, \mathrm{B} 6 \text { (pyridoxine) } 1.4 \\
\mathrm{mg}, \mathrm{B} 121.5 \mu \mathrm{g}, \text { C } 40 \mathrm{mg}, \mathrm{D} 10 \mu \mathrm{g} \text { (after age } 65 \text { ), E } \\
10 \mathrm{mg} \\
\text { Calcium } 700 \mathrm{mg} \text {, iron } 8.7 \mathrm{mg} \text {, zinc } 9.5 \mathrm{mg} \text {, selenium } \\
75 \mu \mathrm{g}, \text { phosphorus } 550 \mathrm{mg} \text {, magnesium } 300 \mathrm{mg}, \\
\text { copper } 1.2 \mathrm{mg} \text {, iodine } 140 \mu \mathrm{g}\end{array}$ \\
\hline Women $\geq 50^{31} 32$ & $\begin{array}{l}\text { Vitamins A } 600 \mu \mathrm{g}, \mathrm{B} 1 \text { (thiamine) } 0.8 \mathrm{mg}, \mathrm{B} 2 \\
\text { (riboflavin) } 1.1 \mathrm{mg} \text {, niacin } 12 \mathrm{mg}, \mathrm{B} 6 \text { (pyridoxine) } 1.2 \\
\mathrm{mg}, \mathrm{B} 121.5 \mu \mathrm{g}, \mathrm{C} 40 \mathrm{mg}, \mathrm{D} 10 \mu \mathrm{g} \text { (after age } 65 \text { ), E } \\
10 \mathrm{mg} \\
\text { Calcium } 700 \mathrm{mg} \text {, iron } 8.7 \mathrm{mg} \text {, zinc } 7.0 \mathrm{mg} \text {, selenium } \\
60 \mu \mathrm{g}, \text { phosphorus } 550 \mathrm{mg} \text {, magnesium } 270 \mathrm{mg}, \\
\text { copper } 1.2 \mathrm{mg} \text {, iodine } 140 \mu \mathrm{g}\end{array}$ \\
\hline
\end{tabular}

umn). For example, two trials recruited exclusively from nursing homes, ${ }^{22} 28$ and one trial ${ }^{24}$ included a much higher proportion of people with type 2 diabetes $(39 \%)$ than any of the others. In that trial, subjects younger than 65 were also recruited, but we excluded those from our analysis. In the original trial report, ${ }^{24} \mathrm{a}$ subgroup analysis by diabetes status was carried out, and nearly
Table 3 Reporting of infections by different definition of outcome (binary)

\begin{tabular}{|c|c|c|c|}
\hline Study (location) & $\begin{array}{l}\text { Mean days of } \\
\text { infection }\end{array}$ & At least one infection & Infection rate \\
\hline $\begin{array}{l}\text { Chavance et al } \\
1993 \\
{\text { (France })^{21}}^{21}\end{array}$ & & & $X$ \\
\hline $\begin{array}{l}\text { Girodon et al } \\
1999 \\
\text { (France) })^{22} \\
\end{array}$ & & $X$ & \\
\hline $\begin{array}{l}\text { Chandra } 1992 \\
\text { (United } \\
\text { States) }\end{array}$ & $X$ & & \\
\hline $\begin{array}{l}\text { Barringer et al } \\
2003 \text { (United } \\
\text { States) } \text { ) }^{24}\end{array}$ & & $X$ & \\
\hline $\begin{array}{l}\text { Graat et al 2002, } \\
\text { (Netherlands) }^{25}\end{array}$ & & $X$ & $X$ \\
\hline 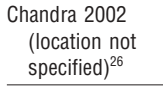 & $X$ & & \\
\hline $\begin{array}{l}\text { Jain } 2002 \\
\quad \text { (India })^{27}\end{array}$ & $X$ & & $X$ \\
\hline $\begin{array}{l}\text { Girodon et al } \\
1997 \\
\text { (France) }^{28}\end{array}$ & & & $X$ \\
\hline $\begin{array}{l}\text { Total instances } \\
\text { reported }\end{array}$ & 3 & 3 & 4 \\
\hline
\end{tabular}

all the intervention effect was found to the attributed to the diabetic patients (relative risk for people with type 2 diabetes 0.18 (0.07 to 0.44 ), and for people without diabetes 0.98 (0.68 to 1.41)). A further observation is that the most beneficial effect sizes were observed in small studies, which may mean this literature is subject to publication bias. As noted in table 1, loss to follow-up in some trials was considerable, which could induce bias in those studies. Other factors that may influence outcome include the length of study follow-up and the seasonal changes it covered, which infections were being investigated and how they were measured, and the quality of the studies.

\section{Limitations of the study}

We identified only a modest number of relevant studies. This limited the assessments of publication bias and the formal exploration of the considerable heterogeneity between studies. A further limitation was that considerable variability existed in the outcome definitions used to report infections (table 3). However, it is noteworthy that in the two instances when two outcomes were reported by a single trial, they gave similar results, implying, perhaps, that definition of outcome is not the most important source of variation. Disappointingly, no more than four studies reported any one outcome. The potentially conflicting results of the three different outcome measures could potentially be attributed to the selection of the specific trials that report that outcome. In an attempt to obtain more compatible data, we contacted authors of six of the trials and requested further information and sent a reminder when no reply arrived after the first query. Unfortunately no additional data were supplied for any of the trials.

\section{Comparison with previous studies}

Although one previous paper has reviewed the role of micronutrients in preventing infections in elderly people,,$^{33}$ to the best of our knowledge no previous systematic review or meta-analysis of the use of micronutrients in preventing infections in elderly people has ever been undertaken.

\section{Implications for research}

Large heterogeneity between the results of the different studies was observed. One reason for the relatively small number of tri- 


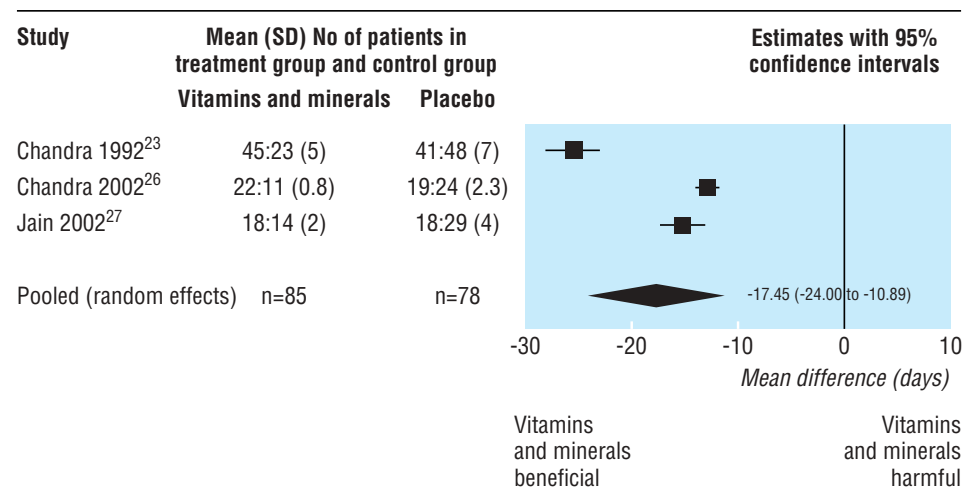

Fig 2 Random effects meta-analysis of outcome: mean difference in number of days of infection between multivitamin+supplement and placebo groups in 12 months

als included in this review is that many previous studies examined only immunological markers (which may or may not translate to similar effects in clinical outcomes). Therefore, future studies should look at the clinical end points (infections, preferably using a common outcome definition). A further source of design variability between existing studies is the composition of the supplements used. Therefore, a multi-arm trial comparing different doses of micronutrients may be appropriate to establish decisively whether they are effective, and if so, whether some doses are superior to others. Additionally, the target populations for future trials should be thought about carefully as results show that the intervention effect is potentially not constant across populations (nutritional status, frailty, type 2 diabetes status, etc). Finally, it seems sensible to have a minimum follow up period of 12 months to provide full exposure to seasonal changes. Such a randomised controlled trial would provide valuable further evidence, allowing a subsequent update of this meta-analysis. Further, if future studies proved the intervention to be effective an economic evaluation of such a policy would need to be done, because of the cost implications of the widespread uptake of supplements.

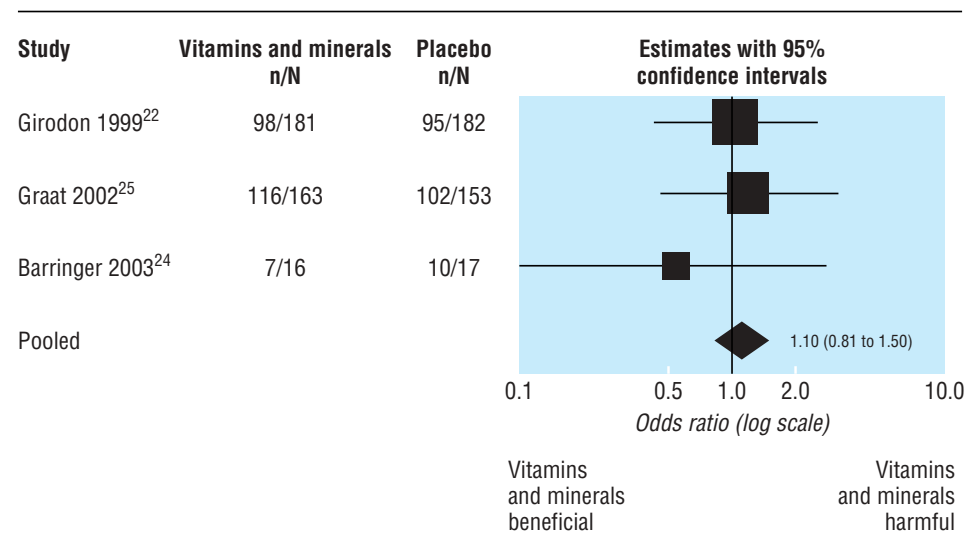

Fig 3 Fixed effect meta-analysis of outcome: odds ratio for at least one infection during the study period between multivitamin+supplement and placebo groups

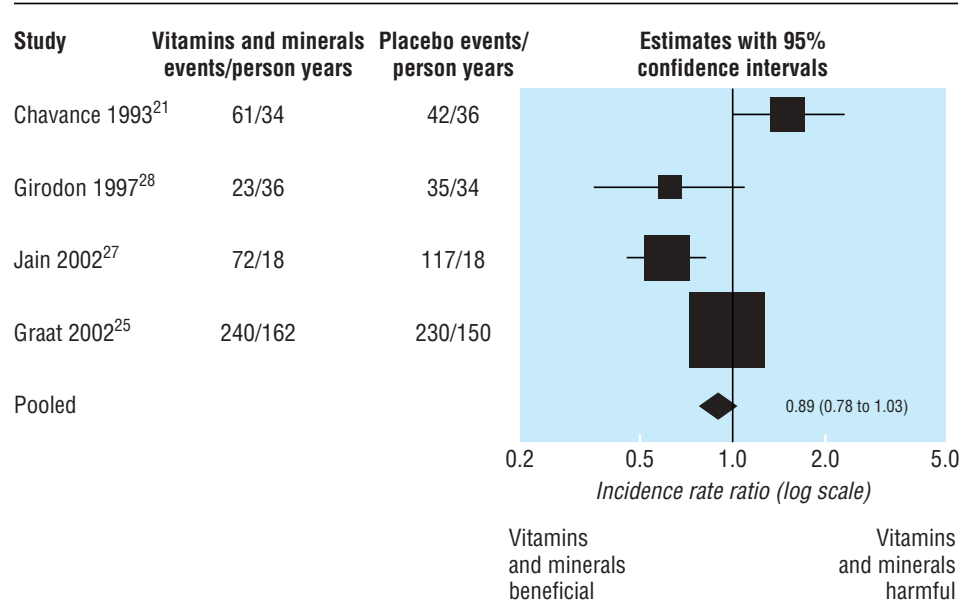

Fig 4 Fixed effect meta-analysis of outcome: incidence rate ratio for infection between multivitamin+supplement and placebo groups 


\section{What is already known on this topic}

Ageing is associated with an increased susceptibility to infection

Currently, interest is great in the use of multivitamins and mineral supplements, with the hope of preventing infections

\section{What this study adds}

The evidence for routine use of multivitamin and mineral supplements to reduce infections in the elderly is weak and conflicting

Therefore the evidence does not support a policy recommending the routine use of such supplements in all elderly people

Further randomised controlled trials using consistent outcome measures are needed before routine use can be recommended

\section{Implications for practice}

Currently, not enough evidence exists to recommend the routine use of micronutrient supplements for an elderly population. However, the results of this review are sufficiently encouraging to warrant further and more expansive studies in this area of considerable public health importance.

We thank Catherine Beverly, systematic reviews information officer, University of Sheffield, and Mary Edmunds Otter, clinical effectiveness information librarian, University of Leicester, for assistance and advice on literature searching and for updating the literature search; Nicola Cooper for helpful comments on an earlier draft of this paper; and Trevor Sheldon for very insightful review comments.

Contributors: Conception and design of the study, data extraction, analysis, and interpretation, drafting, and revising of the article were all carried out be AEK and AJS. AEK and AJS are joint first authors of the paper. AEK is guarantor.

Funding: None.

Conflict of interest: None declared.

Ethical approval: Not required.

1 Gershwin ME. Trace metals and immune function in the elderly. Comprehensive Ther 1987; 13:18-23.

2 Coni N, Webster S. Lecture notes on geriatrics. 5th ed. Oxford: Blackwell Science, 1998.

3 Munro H, Danford D. Nutrition, aging, and the elderly, human nutrition, a comprehensive Munro H, Danford D. Nutrition, aging, and the
treatise. Vol 6. New York: Plenum Press, 1989.

4 Yoshikawa TT. Perspective: Aging and infectious diseases: past, present, and future. $J$ Infect Dis 1997;176:1053-7.

5 Bender DA. Daily doses of multivitamin tablets. BMJ 2002;325:173-4.

6 Fawzi W, Stampfer MJ. A role for multivitamins in infections? Ann Intern Med 2003;138:430-1.

7 Pike J, Chandra RK. Effect of vitamin and trace element supplementation on immune indices in healthy elderly. Internat J Vit Nutr Res 1995;65:117-20.

8 Galan P, Preziosi P, Monget AL, Richard MJ, Arnaud J, Lesourd B, et al. Effects of trace element and/or vitamin supplementation on vitamin and mineral status, free radical metabolism and immunological markers in elderly long term-hospitalized subjects. Internal J Vit Nutr Res 1997;67:450-60.

9 Kemp F, Li W, DeCandia J, Denny T, Oleske J, Skurnick J, et al. Effects of multivitamin and antioxidant administration on serum micronutrients and immunity in older people. FASEB J 2001;15:A293.

10 Talbott MC, Miller LK, Kerkvliet N. Pyridoxine supplementation: effect of lymphocyte response in elderly persons. Am J Clin Nutr 1987;46:559-64.

11 Bogden JD, Bendich A, Kemp FW, Bruening KS, Shurnick JH, Denny T, et al. Daily micronutrient supplements enhance delayed-hypersensitivity skin test responses in older people. Am J Clin Nutr 1994;60:437-47.

12 Wood RJ, Suter PM, Russell RM, et al. Beta-carotene and selenium supplementation enhances immune response in aged humans. Integrative Med 1999;212:85-92.

13 Boardley D, Fahlman M. Micronutrient supplementation does not attenuate seasonal decline of immune system indexes in well-nourished elderly women. J Am Diet Assoc 2000;100:356-9.

14 McKay DL, Perrone G, Rasmussen H, Dallal G, Hartman W, Cao G, et al. The effects of a multivitamin/mineral supplement on micronutrient status, antioxidant capacity and cytokine production in healthy older adults consuming a fortified diet. J Am Coll Nutr 2000;19:613-21.

15 Fortes C, Forastiere F, Agabiti N, Fano V, Pacifici R, Virgili F, et al. The effect of zinc and vitamin A supplementation on immune response in an older population.J Am Geriatr Soc 1998;46:19-26.

16 Penn ND, Purkins L, Kelleher J, Heatley RV, Mascie-Taylor BH, Belfield PW. The effect of dietary supplementation with vitamins $\mathrm{A}, \mathrm{C}$ and $\mathrm{E}$ on cell-mediated immune function in elderly long-stay patients: a randomised controlled trial. Age Aging 1991;20:169tion 74.

17 Chandra RK. Vitamin and trace-element supplementation in healthy elderly persons reduced the frequency of infection and nutritional deficiencies and improved immune response. ACPJClub 1993;118:34

18 Graat JM, Schouten EG, Kok EJ. Neither vitamin E nor multivitamin with minerals prevent respiratory infection among elderly. Focus Alternat Complement Ther 2003;8:37-9.

19 Jadad AR, Moore RA, Carroll D, Jenkinson C, Reynolds DJ, Gavaghan DJ, et al. Assessing the quality of reports of randomised clinical trials: Is blinding necessary? Controlled clinical trials 1996:17:1-12.

20 Moher D, Cook DJ, Eastwood S, Olkin I, Rennie D, Stroup DF. Improving the quality of reports of meta-analysis of randomised controlled trials: the QUOROM statement. Review. Lancet 1999;354:1896-1900.

21 Chavance M, Herbeth B, Lemoine A, Zhu BP. Does multivitamin supplementation prevent infections in healthy elderly subjects?. Int J Vitam Nutr Res 1993;63:11-6.

22 Girodon F, Galan P, Monget AL, Boutron-Ruault MC, Brunet-Lecomte P, Preziosi P, et al. Impact of trace elements and vitamin supplementation on immunity and infections in institutionalised elderly patients. Arch Intern Med 1999;159:748-54.

23 Chandra RK. Effect of vitamin and trace-element supplementation on immune responses and infection in elderly subjects. Lancet 1992;340:1124-7.

24 Barringer TA, Kirk JK, Santaniello AC, Foley KL, Michielutte R. Effect of multivitamin and mineral supplement on infection and quality of life. Ann Intern Med 2003;138:36571.

25 Graat JM, Schouten EG, Kok FJ. Effect of daily vitamin E and multivitamin-mineral supplementation on acute respiratory tract infections on elderly persons. JAMA supplementation

26 Chandra RK. Influence of multinutrient supplement on immune responses and infection-related illness in 50-65 year old individuals. Nutr Res 2002;22:5-11.

27 Jain AL. influence of vitamins and trace-elements on the incidence of respiratory infection in the elderly. Nutr Res 2002;22:85-7.

28 Girodon F, Lombard M, Galan P, Brunet-Lecomte P, Monget AL, Arnaud J, et al. Effect of micronutrient supplementation on infection in institutionalized elderly subjects. Ann Nutr Metab 1997;41:98-107.

29 Higgins JPT, Thompson SG, Deeks JJ, Altman DG. Measuring inconsistency in meta-analyses. BMJ 2003;327:557-60.

30 Goodwin JS, Garry PJ. Relationship between megadose vitamin supplementation and immunological function in a healthy elderly population. Clin Exp Immunol 1983;51:647-53

31 Department of Health. Dietary reference values for food energy and nutrients for the United Kingdom. Report on health and social subjects. 1st ed. London: HMSO. 1991. (No 41.)

32 Expert Group on Vitamins and Minerals. Safe upper levels for vitamins and minerals. London: Stationery Office, 2003.

33 High KP. Nutritional strategies to boost immunity and prevent infection in elderly individuals. Aging Infect Dis 2001;33:1892-900.

doi 10.1136/bmj.38399.495648.8F

Chemical Pathology Department, Royal Hallamshire Hospital, Sheffield S10 2JF Alia El-Kadiki specialist registrar

Department of Health Sciences, University of Leicester, Leicester LE1 6TP Alexander J Sutton senior lecturer in medical statistics

Correspondence to: A El-Kadiki alia@elkadiki.fsnet.co.uk 